\title{
Methane production induced by dimethylsulfide in surface water of an upwelling ecosystem
}

\author{
Lennin Florez-Leiva ${ }^{a}$, Ellen Damm ${ }^{\mathrm{b}}$, Laura Farías ${ }^{\mathrm{c}, \mathrm{d}, *}$ \\ ${ }^{a}$ Graduate Program in Oceanography, Department of Oceanography, University of Concepcion, Casilla 160-C, Chile \\ ${ }^{\mathrm{b}}$ Alfred Wegener Institute for Polar and Marine Research, P.O. Box 12061, 27515 Bremerhaven, Germany \\ ${ }^{\mathrm{c}}$ Laboratorio de Procesos Oceanográficos y Clima, Concepción, Chile \\ ${ }^{\mathrm{d}}$ Center for Climate and Resilience Research $\left(C R^{2}\right)$, Chile
}

\section{A R T I C L E I N F O}

\section{Article history:}

Received 13 August 2012

Received in revised form 11 March 2013

Accepted 17 March 2013

Available online 2 April 2013

\begin{abstract}
A B S T R A C T
Coastal upwelling ecosystems are areas of high productivity and strong outgassing, where most gases, such as $\mathrm{N}_{2} \mathrm{O}$ and $\mathrm{CH}_{4}$, are produced in subsurface waters by anaerobic metabolisms. We describe seasonal $\mathrm{CH}_{4}$ variation as well as potential mechanisms producing $\mathrm{CH}_{4}$ in surface waters of the central Chile upwelling ecosystem $\left(36^{\circ} \mathrm{S}\right)$. Surface waters were always supersaturated in $\mathrm{CH}_{4}$ (from $125 \%$ up to $550 \%$ ), showing a clear seasonal signal triggered by wind driven upwelling processes (austral springsummer period), that matched with the periods of high chlorophyll-a and dimethylsulfoniopropionate (DMSP) levels. Methane cycling experiments, with/without the addition of dimethylsulfide (including ${ }^{13} \mathrm{C}$-DMS) and acetylene (a nonspecific inhibitor of $\mathrm{CH}_{4}$ oxidation) along with monthly measurements of $\mathrm{CH}_{4}$, DMSP and other oceanographic variables revealed that DMS can be a $\mathrm{CH}_{4}$ precursor. $\mathrm{Net}^{\mathrm{CH}}$ cycling rates (control) fluctuated between -0.64 and $1.44 \mathrm{nmol} \mathrm{L}^{-1} \mathrm{~d}^{-1}$. After the addition of acetylene, $\mathrm{CH}_{4}$ cycling rates almost duplicated relative to the control, suggesting a strong methanotrophic activity. With a spike of DMS, the net $\mathrm{CH}_{4}$ cycling rate significantly increased relative to the acetylene and control treatment. Additionally, the $\delta^{13} \mathrm{C}$ values of $\mathrm{CH}_{4}$ at the end of the incubations (after addition of ${ }^{13} \mathrm{C}$ enriched-DMS) were changed, reaching $-32 \%$ PDB compared to natural values between $-44 \%$ and $-46 \%$ PDB. These findings indicate that, in spite of the strong $\mathrm{CH}_{4}$ consumption by methanotrophs, this upwelling area is an important source of $\mathrm{CH}_{4}$ to the atmosphere. The effluxes are derived partially from in situ surface production and seem to be related to DMSP/DMS metabolism.
\end{abstract}

(c) 2013 Elsevier Ltd. All rights reserved.

\section{Introduction}

Methane is the most abundant hydrocarbon and a major greenhouse gas (20 times more effective in its radiative forcing than $\mathrm{CO}_{2}$ ) which plays an important role in the Earth's radiative balance (Quay et al., 1999). It is mainly produced by biological (anaerobic) activity and accumulated through geological processes such as gas hydrate or other $\mathrm{CH}_{4}$ deposition pathways (Wuebbles and Hayhoe, 2002). The ocean surface acts as a net source of atmospheric $\mathrm{CH}_{4}$, although its release is minor compared with natural emissions on land (Cicerone and Oremland, 1988). Estimates of annual oceanic $\mathrm{CH}_{4}$ emission vary greatly between 0.4 (Bates et al., 1996) and 11-18 $\mathrm{Tg} \mathrm{C}^{-1}$ (Bange et al., 1994) and part of this uncertainty could be associated with low spatial resolution. Regional $\mathrm{CH}_{4}$ emissions fluctuate widely; for example, surface waters of subtropical oceanic gyres are almost in equilibrium (100\%) or slightly supersaturated $(>100 \%)$ with the atmosphere (Holmes et al., 2000) whereas

\footnotetext{
* Corresponding author at: Graduate Program in Oceanography, Department of Oceanography, University of Concepcion, Casilla 160-C, Chile.

E-mail address: Ifarias@profc.udec.cl (L. Farías).
}

coastal areas can attain up to $500 \%$ surface $\mathrm{CH}_{4}$ saturation (Sansone et al., 2001; Rehder et al., 2002).

Coastal areas cover only a small portion of the world's oceans but release up to $75 \%$ of the overall marine $\mathrm{CH}_{4}$ flux into the atmosphere. Among costal ecosystems, eastern boundary coastal upwelling areas could be major sources or hotspots of marine $\mathrm{CH}_{4}$ (Monteiro et al., 2006; Kock et al., 2008; Naqvi et al., 2010). There, a combination of physical and biological processes must co-occur to produce high air-sea $\mathrm{CH}_{4}$ efflux. Physical forcing related to favorable upwelling winds promotes intense vertical advection of subsurface waters, driving fertilization but also strong outgassing of $\mathrm{N}_{2} \mathrm{O}$ and $\mathrm{CH}_{4}$ (Hatton et al., 1999; Bange, 2006; Kock et al., 2008; Cornejo and Farias, 2012). On the other hand, high biological productivity linked to natural hypoxia occurs during coastal upwelling events, favoring the existence of anaerobic/microaerophilic processes which mediate $\mathrm{CH}_{4}$ cycling; most of them in the sediments but also in free- or attached living pelagic or benthic microorganisms (Monteiro et al., 2006).

Considerable focus is placed on excess quantities of biogenic $\mathrm{CH}_{4}$ in surface oceans, apparently generated by a local methanogenesis in oxygenated surface waters (Karl et al., 2008; Rudd and 
Taylor, 1980). Given that $\mathrm{CH}_{4}$ microbial production does not occur in oxic environments, this phenomenon is called the "methane paradox" (Wolfe, 1971; Lamontagne et al., 1973). A number of studies suggest that $\mathrm{CH}_{4}$ excess in surface waters results from several in situ sources other than vertical advection of subsurface waters (Scranton and Brewer, 1977). Earlier studies suggest that $\mathrm{CH}_{4}$ production is carried out by microorganisms living within micro-environments which occur in dead cells, fecal pellets or large organisms (Scranton and Brewer, 1977). Other sites and mechanisms of $\mathrm{CH}_{4}$ generation include zooplankton biomass (Traganza et al., 1979), the digestive tracts of fish (Lamontagne et al., 1973; Oremlad, 1979; Brooks et al., 1981) and the degradation of particulate organic matter (Karl and Tilbrook, 1994). Additional mechanisms for $\mathrm{CH}_{4}$ formation in oxic environments are via methylphosphonate (MPn) cycling in subtropical gyres which are phosphate-stressed (Karl et al., 2008) and via DMSP in polar oligotrophic waters which are nitrate-stressed (Damm et al., 2010).

Methanogens are mainly Archaea that produce $\mathrm{CH}_{4}$ by dismutation of acetate or pyruvate or by catabolism of a wide range of methylated compounds. However also bacteria may being methylotroph, using a series of methylated compounds, including methylated sulfur compounds such as dimethylsulfoniopropionate (DMSP) and dimethylsulfide (DMS) (Neufeld et al., 2008). This metabolism is referred as methylotrophic methanogenesis (Sowers and Ferry, 1983).

Both DMSP and DMS are S- and C-containing organic compounds that are biosynthesized by phytoplankton (DMSP) and assimilated and degraded by bacterioplankton (Kiene et al., 2000). DMSP is transformed to DMS, a volatile compound influencing global temperature but with a cooling effect, through its effects on cloud cover (Andreae, 1990). Functional genomics applied to natural communities recently reveals two different DMSP degrading pathways mediated by different genes and, therefore, microorganisms (Moran et al., 2012); one of them is the demethylation of DMSP facilitating retention of carbon and sulfur in the marine microbial food web and another is by cleavage of DMSP to DMS with important consequences for the ocean-atmosphere sulfur flux.

In this study, we measured $\mathrm{CH}_{4}$ cycling throughout processes that consume $\mathrm{CH}_{4}$ as the only source of carbon (e.g. methanotrophy) and those that regenerate $\mathrm{CH}_{4}$ in order to quantify net and gross rates of $\mathrm{CH}_{4}$ in surface waters. More importantly, we present the first evidence that DMS cycling generates $\mathrm{CH}_{4}$ in surface waters off central Chile $\left(36^{\circ} \mathrm{S}\right)$, an area subjected to intense upwelling events which occur seasonally during austral spring-summer.

\section{Methods}

\subsection{Study area}

The study area is on the continental shelf off central Chile where the COPAS Time Series station is located $\left(36^{\circ} 0.80^{\prime} \mathrm{S}-73^{\circ} 07.75^{\prime} \mathrm{W}\right.$, $92 \mathrm{~m}$ depth, Fig. 1). It is representative of the oceanographic conditions of the coastal upwelling system. Monthly cruises were conducted as part of the MILOCO time series program. Intensive MILOCO biogeochemical oriented cruises during upwelling periods were conducted between 2009 and 2011, in order to study the temporal variability in physical-chemical properties (field measurements) and elucidate the processes responsible for $\mathrm{CH}_{4}$ cycling at surface waters (experimental assays).

\subsection{Field measurements}

Water samples for gas $\left(\mathrm{O}_{2}, \mathrm{CH}_{4}\right)$, DMSP, nutrients and pigments (in this successive order) were collected with a rosette (12-L Niskin

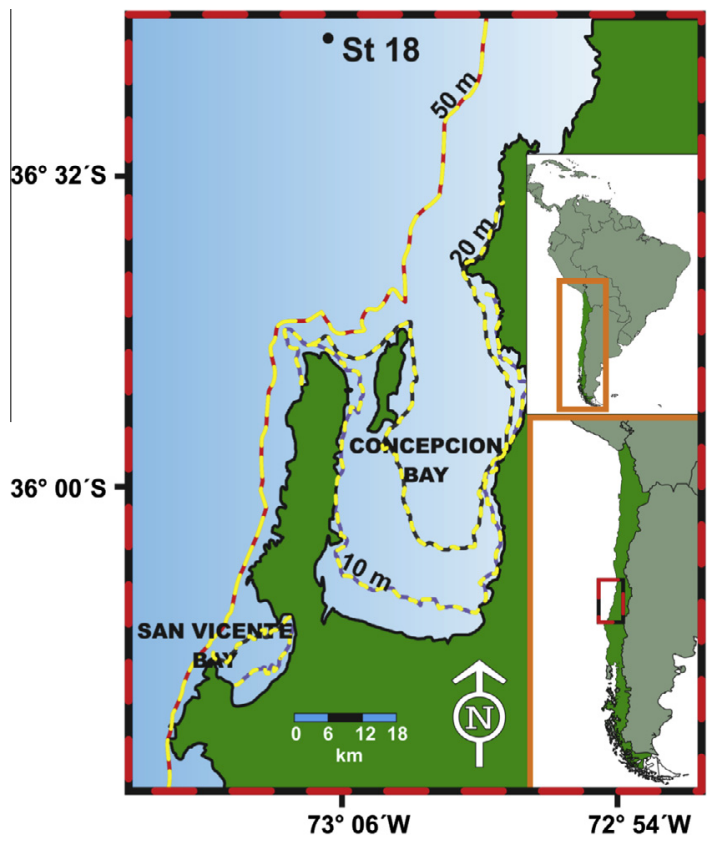

Fig. 1. Map indicating the location of Station $18\left(36^{\circ} 30^{\prime} \mathrm{S}\right.$ and $\left.73^{\circ} 07^{\prime} \mathrm{W}\right)$ sampled monthly by the COPAS oceanographic center as part of a physical-chemicalbiological integrated time-series study since 2002. Bathymetric lines (meters) are shown.

bottles) equipped with a CTD (Seabird SBE 43). Discrete samples were obtained at nine depths between the surface and $90 \mathrm{~m}$, with $3-4$ sampling depths in the photic layer $(2,5,10$ or 15 and $20 \mathrm{~m})$. For dissolved $\mathrm{O}_{2}$ (triplicate), seawater samples were taken in an iodimetric flask and analyzed with an automatic version of the Winkler method, based on a photometric end point with a Dosimat 665. For dissolved $\mathrm{CH}_{4}$ (triplicate), seawater samples were taken in $20 \mathrm{~mL}$ headspace vials and carefully sealed to avoid trapping air, with rubber stoppers and screw caps. The samples were poisoned with $50 \mu \mathrm{L}$ saturated $\mathrm{HgCl}_{2}$ and stored until their analysis in the laboratory. In the laboratory and just before analysis, $5 \mathrm{~mL}$ of water from the vial was replaced with helium in order to create a headspace. Then, the water-headspace sample was equilibrated at $40{ }^{\circ} \mathrm{C}$ (shaking continuously) and $\mathrm{CH}_{4}$ from the headspace was manually analyzed with a gas chromatograph with a flame ionization detector (Schimadzu 17A) through a capillary column GS-Q (J \& W, $0.53 \mathrm{~mm} \times 30 \mathrm{~m})$ at $30{ }^{\circ} \mathrm{C}$ oven temperature and a $4 \mathrm{ml} \mathrm{min}^{-1} \mathrm{col}-$ umn flow (Farías et al., 2009). A calibration curve was made with 4 points (He, synthetic air, $2 \mathrm{ppm}$ and $10 \mathrm{ppm}$ ) and the detector linearly responded to this concentration range. The analytical error for the $\mathrm{CH}_{4}$ analysis was less than $5 \%$.

Dissolved dimethylsulphoniopropionate (DMSPd) was measured according to published procedures (Kiene and Slezak, 2006). DMSPt (DMSP total) samples were directly collected from Niskin bottles as unfiltered seawater samples and stored in the dark in $250 \mathrm{~mL}$ polycarbonate bottles and during the 2010-2011 upwelling season until their return to the laboratory (Dauphin Island Laboratories of the University of Alabama, USA) for further analysis. DMSPd and DMSPt samples were added to $\mathrm{NaOH}$ in a sealed vial and the resulting DMS quantified by GC (Kiene and Slezak, 2006; Rellinger et al., 2009). The difference between DMSPt and DMSPd results in DMSPp (particulate DMSP).

Nutrient measurements $\left(\mathrm{NO}_{3}^{-}, \mathrm{NO}_{2}^{-}\right.$and $\left.\mathrm{PO}_{4}^{3-}\right)$ were performed for each depth; samples were taken in $20 \mathrm{~mL}$ polyethylene flasks and analyzed after using an automatic SEAL Autoanalyser (analytical error better than 3\%). Samples for Chlorophyll-a (Chl-a) was filtered onto a glass-fiber filter, and the filter in triplicate was 
immediately frozen $\left(-20^{\circ} \mathrm{C}\right)$. Samples were kept until later analysis by fluorometry (Turner Design AU-10) previously acidification following Parsons et al. (1985).

The $\delta^{13} \mathrm{C}-\mathrm{CH}_{4}$ values were determined by a Delta XP plus Finnigan mass spectrometer. The extracted gas was purged and trapped with PreCon equipment (Finnigan) to pre-concentrate the sample. Depending on the $\mathrm{CH}_{4}$ concentration, the reproducibility derived from duplicates was $0.5-1 \%$. All isotopic ratios were given a $\delta$ notation relative to the Pee Dee Belemnite (PDB) standard (Craig, 1957; Damm et al., 2010).

\subsection{Experimental assays}

During biogeochemical oriented cruises undertaken in the upwelling season (see Table 1), on board $\mathrm{CH}_{4}$ assessments were done in order to assess $\mathrm{CH}_{4}$ cycling rates and determine the mechanism for $\mathrm{CH}_{4}$ production and/or consumption. For this purpose, seawater taken at $10 \mathrm{~m}$ depth (a depth where a Chl-a peak is generally found) was dispensed into 2-L double-laminated aluminumpolyethylene bags. Each bag had a hose/valve with a septum through which all the different treatments were injected. A permeability test was performed prior to the experiment (for details see Farías et al., 2009). The net or gross $\mathrm{CH}_{4}$ cycling rate was determined by incubating the bags for $12 \mathrm{~h}$ (total incubation time) at a temperature $\left(14{ }^{\circ} \mathrm{C}\right)$ close to in situ conditions. Experiments without any additions (control) represent a net $\mathrm{CH}_{4}$ cycling rate (production minus consumption); while experiments with additions and with ultrapure acetylene $\left(\mathrm{C}_{2} \mathrm{H}_{2}\right.$ final concentration of $10 \% \mathrm{v} /$ $v)$, whose effect has been described as inhibiting the $\mathrm{CH}_{4}$ monooxygenating (MMO) enzyme and the growth of methanotrophs (Prior and Dalton, 1985) represent gross $\mathrm{CH}_{4}$ cycling rate. However, it is important to note that $\mathrm{C}_{2} \mathrm{H}_{2}$ is a very unspecific inhibitor, blocking the activity of methanogens (Sprott et al., 1982) and nitrifying microorganisms (Hyman and Arp, 1992) as well. Thus, if methanogens (mainly associated with micro-niches) are absent in the oxic water and if methanotrophs are active, and they are sensitive to $\mathrm{C}_{2} \mathrm{H}_{2}$, this treatment would lead to reduction of $\mathrm{CH}_{4}$ consumption. Therefore, a $\mathrm{CH}_{4}$ consumption rate by aerobic $\mathrm{CH}_{4}$ oxidation could be estimated from the rate measured in $\mathrm{C}_{2} \mathrm{H}_{2}$ experiments minus the rate quantified in control experiments.

In parallel, ${ }^{13} \mathrm{C}$-DMS (labeled in both $\mathrm{C}$ of methyls groups) experiments were conducted at one standard depth $(10 \mathrm{~m})$ in the time series station. For this purpose, an isotopic solution ( $5 \mu \mathrm{mol} \mathrm{L}^{-1}$ ) was added with a spike of $1 \mathrm{~mL}$ until a final concentration $\sim 6 \mathrm{nmol} \mathrm{L}^{-1}$ in order to determine whether $\mathrm{CH}_{4}$ was produced by DMS through any reaction (e.g., demethylation); the $\mathrm{CH}_{4}$ cycling rate was compared to net $\mathrm{CH}_{4}$ cycling (control) and net apparent production $\left(\mathrm{C}_{2} \mathrm{H}_{2}\right.$ experiment). Finally, poisoned treatments (with $\mathrm{HgCl}_{2}$ ) were performed in order to assess whether biological processes or abiotic reactions were occurring. All additions were slowly injected into the bags through a septum with gastight syringes. Subsamples (triplicate) of each treatment were retrieved from the bags (one or two bags per experiment) into $20 \mathrm{~mL} \mathrm{GC}$ vials for $\mathrm{CH}_{4}$ analysis at different times $(0,6$ and $12 \mathrm{~h}$ ) by applying pressure on the bags; this water was poured into GC bottles $(20 \mathrm{~mL})$. For each incubation time, three GC bottles with incubated water were injected with $50 \mu \mathrm{L}$ of saturated $\mathrm{HgCl}_{2}$ in order to stop all biological reactions; the bottles were then sealed with rubber stoppers and metallic caps.

Finally, the isotopic composition of $\mathrm{CH}_{4}$ was measured during incubations in September 2010 and January 2011, before and after the addition of the ${ }^{13} \mathrm{C}$-labeled compound with $99 \%$ of purity (Cambridge Isotope Laboratories, USA). Labeled DMS $\left({ }^{13} \mathrm{C}\right.$-DMS) was added to the bags at a final concentration of $6 \mathrm{nmol} \mathrm{L}^{-1}$ in order to directly assess the origin of $\mathrm{CH}_{4}$ production from organic labeled compounds. The ${ }^{13} \mathrm{C}$-DMS tracer additions was estimated to be close to $30-100 \%$ of ambient concentrations in surface waters which could fluctuated from $<5$ to $15 \mathrm{nmol} \mathrm{L}^{-1}$ in upwelling areas according to Andreae (1985) and Lana et al. (2011). In this study, DMS levels in seawater were not measured. Finally, sub-samples from the bags were taken similar to the experiments described previously, recovering subsample (triplicate) in $20 \mathrm{~mL}$ vials at zero and final time. These subsamples were immediately poisoned and the stable carbon isotopic composition of $\mathrm{CH}_{4}$ accumulated inside the bags was determined.

\subsection{Data analysis}

In order to determine the $\mathrm{CH}_{4}$ isotopic composition and its cycling rate (production and consumption rate experiments), $\mathrm{CH}_{4}$ concentration during incubation (from different treatments and bags) were plotted against time and fitted to a linear $\left[A(t)=A_{0} \pm\right.$ $m * t]$ model using the least squares method; where $t$ is the incubation time, $A_{0}$ is the gas concentration at $t=0$ (after DMS addition), and $m$ is the slope ratio. Slope was calculated from the linear regression, and the rate uncertainties $( \pm)$ were calculated from the linear regression errors. The rate uncertainty for control, $\mathrm{C}_{2} \mathrm{H}_{2}$ and DMS treatments was calculated directly from the standard error of the slope. Propagation of error was estimated for $\mathrm{CH}_{4}$ oxidation rates (control minus acetylene treatments). Student's $t$-test and ANOVA were used to evaluate the significance of slopes and the differences between the treatments. Positive values represented $\mathrm{CH}_{4}$ production or accumulation over time (as in the cases of inhibitors), whereas negative values indicated consumption. $\mathrm{CH}_{4}$ concentration data were analyzed for differences between treatments using a two-way analysis of variance. Data were checked for normality using a Shapiro-Wilk test and for homogeneity with a constant variance test. Differences between treatments (Control, $\mathrm{C}_{2} \mathrm{H}_{2}$ and DMS-spike) were evaluated using one-way ANOVA.

To interpret vertical variation of $\mathrm{CH}_{4}$ and how processes affect concentration, the water column was divided in two layers according with mixing layer (thermocline distribution): (1) well-mixed layer (and also photic) with high $\mathrm{O}_{2}$ content; and (2) subsurface and aphotic layer with $\mathrm{O}_{2}$ deficient waters (see criteria in Farías et al., 2009). $\mathrm{CH}_{4}$ inventories were calculated by numerical integration of data from the surface and subsurface layers based on at

Table 1

Total and dissolved DMSP concentrations, DMSPp:Chl-a ratios and Pearson correlations values.

\begin{tabular}{|c|c|c|c|c|c|}
\hline \multirow[t]{2}{*}{ Month } & \multirow[t]{2}{*}{ DMSPd (nM) } & \multirow[t]{2}{*}{ DMSPt (nM) } & \multirow[t]{2}{*}{ 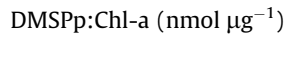 } & \multicolumn{2}{|l|}{ Correlations } \\
\hline & & & & DMSPd-Cl-a & DMSPt-Cl-a \\
\hline September 2010 & $0.33-26.4(5.11)$ & $0.9-60(17.36)$ & 1.21 & 0.68 & $0.84^{*}$ \\
\hline November 2010 & $0.2-21.5(3.65)$ & $1.65-43(15.51)$ & 11.8 & $0.94^{* *}$ & $0.98^{* *}$ \\
\hline December 2010 & $0.4-6.3(1.65)$ & $4.12-25(12.54)$ & 1.07 & 0.03 & $0.69^{*}$ \\
\hline January 2011 & $0.35-20(3.96)$ & $5.10-109(42.81)$ & 28.1 & $0.99^{* *}$ & $0.82^{*}$ \\
\hline
\end{tabular}

Bold values are statistical significant.

${ }^{*} p<0.05$.

$p<0.01$. 
least 4-6 sampled depths by layer. Saturation of $\mathrm{CH}_{4}$ was estimated from the measured and expected $\mathrm{CH}_{4}$ concentration in the water column, corresponding temperature and salinity, and based on equilibrium $\mathrm{CH}_{4}$ concentration with atmospheric $\mathrm{CH}_{4}$ calculations delineated by Weisenburg and Guinasso (1979).

\section{Results}

\subsection{Temporal variability of physical-chemical variables (including $\left.\mathrm{CH}_{4}\right)$}

Temporal variability of physical (temperature and salinity) and chemical $\left(\mathrm{O}_{2}\right.$ and $\left.\mathrm{CH}_{4}\right)$ variables in the water column (from April 2009 to April 2011) is shown in Fig. 2. Temperature (Fig. 2A) is influenced by both the upwelling process (mainly at subsurface waters) and solar radiation (mainly surface waters), both being concurrent in spring-summer. These patterns give the system strong thermal stratification during spring-summer in comparison with fall-winter time. Salinity (Fig. 2B) is also affected by vertical advection of relatively high salinity waters during spring-summer time and by freshwater inputs (rainfall and river discharges) during late fallwinter time. This marked seasonality in terms of both variables is well documented in this region by Sobarzo et al. (2007).

Dissolved $\mathrm{O}_{2}$ levels (Fig. $2 \mathrm{C}$ ) are fully saturated $\left(>200 \mu \mathrm{mol} \mathrm{L}^{-1}\right)$ at the surface throughout the entire study period, but displays a strong vertical gradient below the mixed layer ( $20 \mathrm{~m}$ depth), reaching values as low as $1.0 \mu \mathrm{mol} \mathrm{L}^{-1}$ at bottom depths close to sediments during the upwelling periods (i.e., September-April). In contrast, during non-upwelling periods, i.e., fall-winter time (May-August), dissolved $\mathrm{O}_{2}$ concentrations under $44 \mu \mathrm{mol} \mathrm{L}^{-1}$ are restricted to the bottom waters and high values throughout the water column were observed, usually coincident with periods of strong vertical mixing and winter storms. Dissolved $\mathrm{CH}_{4}$ concentrations (Fig. 2D) show a clear seasonal signal consisting of accumulated $\mathrm{CH}_{4}$ up to $65 \mathrm{nmol} \mathrm{L}^{-1}$ in bottom waters close to sediments during upwelling periods. This period matches low dissolved $\mathrm{O}_{2}$ concentrations and the accumulation of biogenic organic particles from surface waters. In surface waters $\mathrm{CH}_{4}$ levels fluctuate between 3.08 and $16 \mathrm{nmol} \mathrm{L}^{-1}$ (equivalent to $123-550 \%$ saturation), with maximum values found during the upwelling period.

\subsection{Nutrient and chlorophyll-a}

The temporal variability of nutrient and pigment variables in the water column (from April 2009 to April 2011) is shown in Fig. 3. $\mathrm{NH}_{4}^{+}$concentrations (Fig. $3 \mathrm{~A}$ ) in surface waters are highly fluctuating with submicromolar levels in summer time and as high as $1.8 \mu \mathrm{mol} \mathrm{L}^{-1}$ in winter time. $\mathrm{NO}_{3}^{-}$and $\mathrm{PO}_{4}^{3-}$ classically considered as preformed nutrients also display high variability during the study period, ranging from 5.5 to $17 \mu \mathrm{mol} \mathrm{L}^{-1}$ for $\mathrm{NO}_{3}^{-}$and from 0.9 to $1.5 \mu \mathrm{mol} \mathrm{L}^{-1}$ for $\mathrm{PO}_{4}^{3-}$. Most of the time, surface waters never display depleted nutrient concentrations, in spite of high biological production and even strong $\mathrm{NO}_{3}^{-}$and $\mathrm{NH}_{4}^{+}$uptake observed during the development of phytoplankton blooms (Fernandez and Farías, 2012). $\mathrm{PO}_{4}^{3-}$ is in excess relative to the Redfield ratio. Chlorophyll-a levels show peaks during each upwelling season with values fluctuating between 1 and $25.5 \mu \mathrm{g} \mathrm{L}^{-1}$ (Fig. 3D). It is important to note that in winter Chl-a levels are around $1 \mu \mathrm{g} \mathrm{L}^{-1}$. These patterns appear to be associated with not only frequency of fertilizations by vertical advection driven by cumulative upwelling events, but also by phytoplankton structure and composition.

\subsection{Vertical distribution of DMSPd, DMSPt and Chl-a}

Vertical distribution of Chl-a and DMSPp are illustrated in Fig. 4. DMSPp (the difference between total and dissolved DMSP) levels, measured only in spring and summer time of the 2010-2011 years, varied from 7 to $80 \mathrm{nmol} \mathrm{L}^{-1}$. DMSPp peaked at $10-20 \mathrm{~m}$ depth (Fig. 4A-C), except in January 2011 when the highest and variable DMSPp levels (up to $80 \mathrm{nmol} \mathrm{L}^{-1}$ ) are found. In contrast, Chl-a profiles show exponential decreases with increasing depth (according to the photic layer).

DMSPp: Chl-a ratios range from 1.07 (December 2010) to

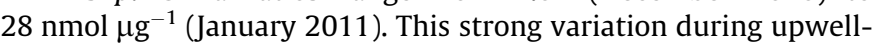
ing period appeared to be affected by changes in the phytoplankton composition as described by Anabalón et al. (2007). Concentrations of DMSPt and DMSPd, along with DMSPp:Chl-a ratios and correlations between Chl-a and DMSP are shown in Table 1. This reveals large variations of DMSP with minimum values $<2 \mathrm{nmol} \mathrm{L}^{-1}$ in both fractions and maximum values of 42.81 and $5.11 \mathrm{nmol} \mathrm{L}^{-1}$ for DMSPt and DMSPd, respectively. Correlations among Chl-a content and DMSPp are always positively and significantly correlated (Table 1 ).

\subsection{Methane cycling in surface water}

Methane cycling rates in the control, acetylene $\left(\mathrm{C}_{2} \mathrm{H}_{2}\right)$ and DMS spike treatments, as well as estimations of aerobic $\mathrm{CH}_{4}$ oxidation rates for different sampling periods are presented in Table 2. Typical time course experiments based on described experimental setup are illustrated in Fig. 5. Rates and standard errors are expressed in $n m o l \mathrm{~L}^{-1} \mathrm{~d}^{-1}$. Net $\mathrm{CH}_{4}$ cycling rates measured in control experiments ( -2.64 to $1.44 \mathrm{nmol} \mathrm{L}^{-1} \mathrm{~d}^{-1}$ ) are usually lower than those rates in the $\mathrm{C}_{2} \mathrm{H}_{2}$ treatments ( 0.96 up to $5.53 \mathrm{nmol} \mathrm{L}^{-1} \mathrm{~d}^{-1}$ ), indicating that most of the time ( 5 of 7 experiments) there are a consumption of $\mathrm{CH}_{4}$ at variable rates. Since the experiments with $\mathrm{C}_{2} \mathrm{H}_{2}$ addition are significantly different $(p<0.05)$ to the control (in 4 of 5 experiments), this trend suggests that there is a sensitive $\mathrm{C}_{2} \mathrm{H}_{2}$ microbial assemblage and that it always lead to a $\mathrm{CH}_{4}$ accumulation higher than control. Thus, this treatment represents a gross $\mathrm{CH}_{4}$ production and it is possible to estimate an aerobic $\mathrm{CH}_{4}$ oxidation rate ranged from 2.91 to $6.50 \mathrm{nmol} \mathrm{L}^{-1} \mathrm{~d}^{-1}$ (through the difference between $\mathrm{C}_{2} \mathrm{H}_{2}$ minus control), precluding any effect of the methanogens if they were active.

The DMS-spiked experiments also increase significantly with respect to $\mathrm{C}_{2} \mathrm{H}_{2}$ and control experiments (in 5 of 7 experiments), with the $\mathrm{CH}_{4}$ cycling rate fluctuating between 1.68 and $4.56 \mathrm{nmol} \mathrm{L}^{-1} \mathrm{~d}^{-1}$ and indicating extra $\mathrm{CH}_{4}$ production using DMS as a substrate. The isotopic composition in $\mathrm{CH}_{4}$ cycling experiments after the addition of similar doses of DMS ( $6 \mathrm{nmol} \mathrm{L}^{-1}$ final concentration) but with methyl groups labeled $\left({ }^{13} \mathrm{C}\right.$-DMS), shows a significantly heavier $\mathrm{CH}_{4}$ isotopic composition $\left(\delta^{13} \mathrm{C}_{-} \mathrm{CH}_{4}\right.$ $\sim-35.43 \%$ to $-43.85 \%$ PDB) than the isotopic composition immediately previous to the tracer additions (time zero; $\delta^{13} \mathrm{C}$ $\mathrm{CH}_{4} \sim-44.71 \%$ o to $-45.72 \%$ o PDB). Fig. 6 illustrates the temporal evolution of conversion/incorporation of the methyl groups to $\mathrm{CH}_{4}$, shown by different extents of ${ }^{13} \mathrm{C}$-enrichments in the end time incubation. Experiments with ${ }^{13} \mathrm{C}$-labeled DMS show recovered dissolved $\mathrm{CH}_{4}$ enriched in ${ }^{13} \mathrm{C}$ after the incubation time, which is significantly less negative than the early days of incubation (Fig. 6). Isotopic fractionation in experiments amended with $\mathrm{HgCl}_{2}$ does not change after incubation (data not shown).

\section{Discussion}

\subsection{Methane content in the water column}

The continental shelf off central Chile is an ecosystem under the influence of wind-driven coastal upwelling, which drives a wellstudied seasonal signal in most physical-chemical variables (e.g., Sobarzo et al., 2007). A typical consequence of the local wind forcing is the fertilization of surface water column that increases 

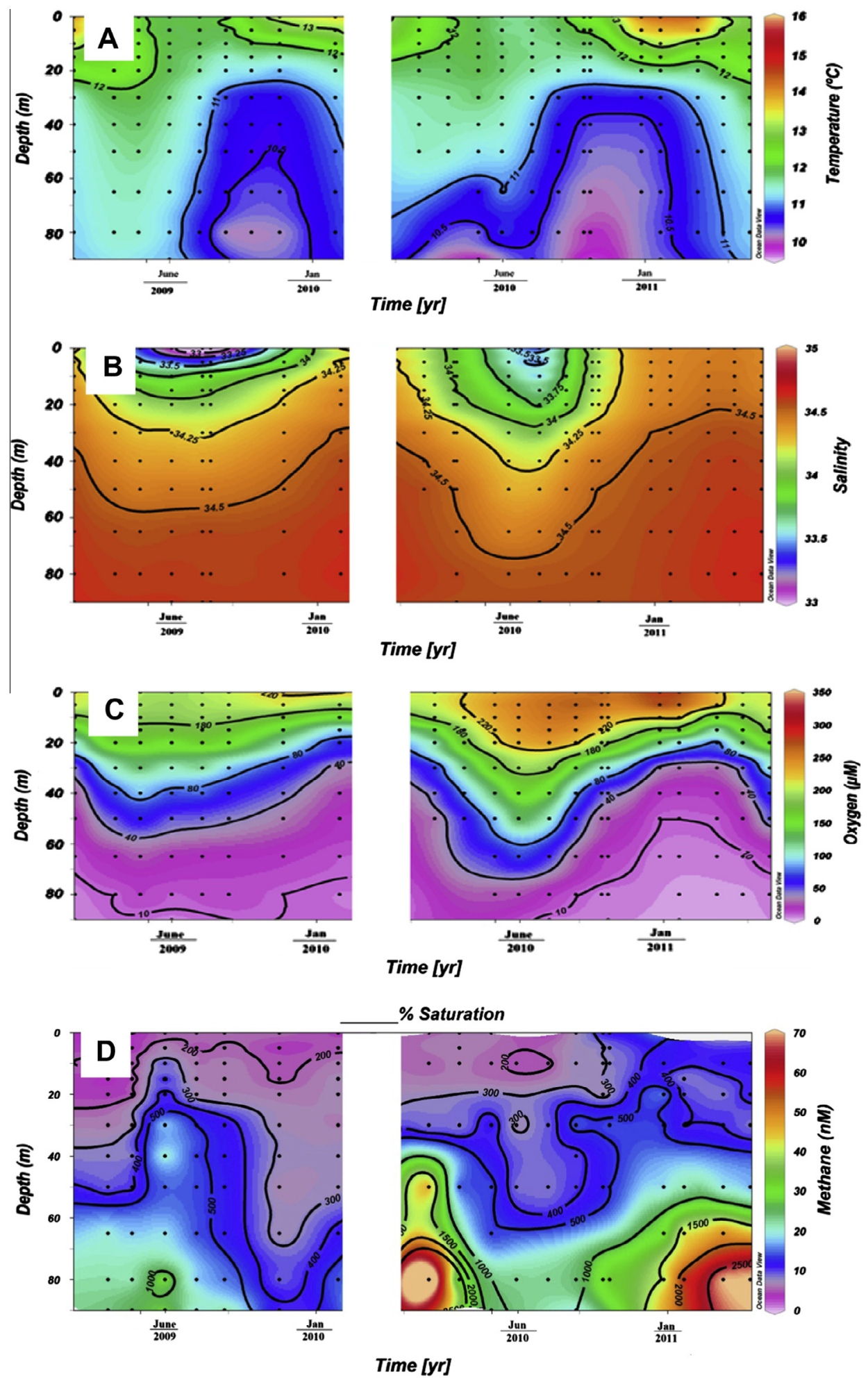

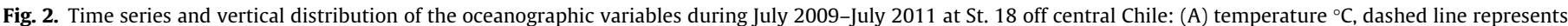

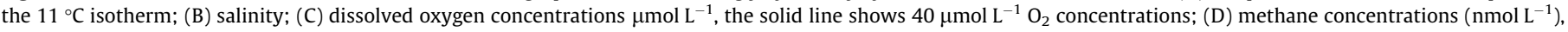
the lines indicate \% saturations. Discontinuity in the data was caused by the February 27 th 2010 Chilean earthquake and tsunami.

primary production during the austral spring-summer (with ranged from 1.2 to $10 \mathrm{~g} \mathrm{C} \mathrm{m}^{-2} \mathrm{~d}^{-1}$, Farías et al., 2009) and also leads to strong outgassing of $\mathrm{N}_{2} \mathrm{O}$ and $\mathrm{CH}_{4}$ (Cornejo et al., 2007; Naqvi et al., 2010).

The sediments of the continental shelf harbor intense anaerobic organic matter remineralization processes as a consequence of strong organic matter sedimentation, which matched periods of suboxia/anoxia (upwelling periods). Thus, methanogenesis in sediments (Ferdelman et al., 1997), as well as the presence of cold seeps (Jessen et al., 2011; Sellanes et al., 2011) could mean that the sediments are an important $\mathrm{CH}_{4}$ source toward the water column.

A marked increase of $\mathrm{CH}_{4}$ with depth is observed in $75 \%$ of the sampling period. This $\mathrm{CH}_{4}$ vertical trend is also associated with a 

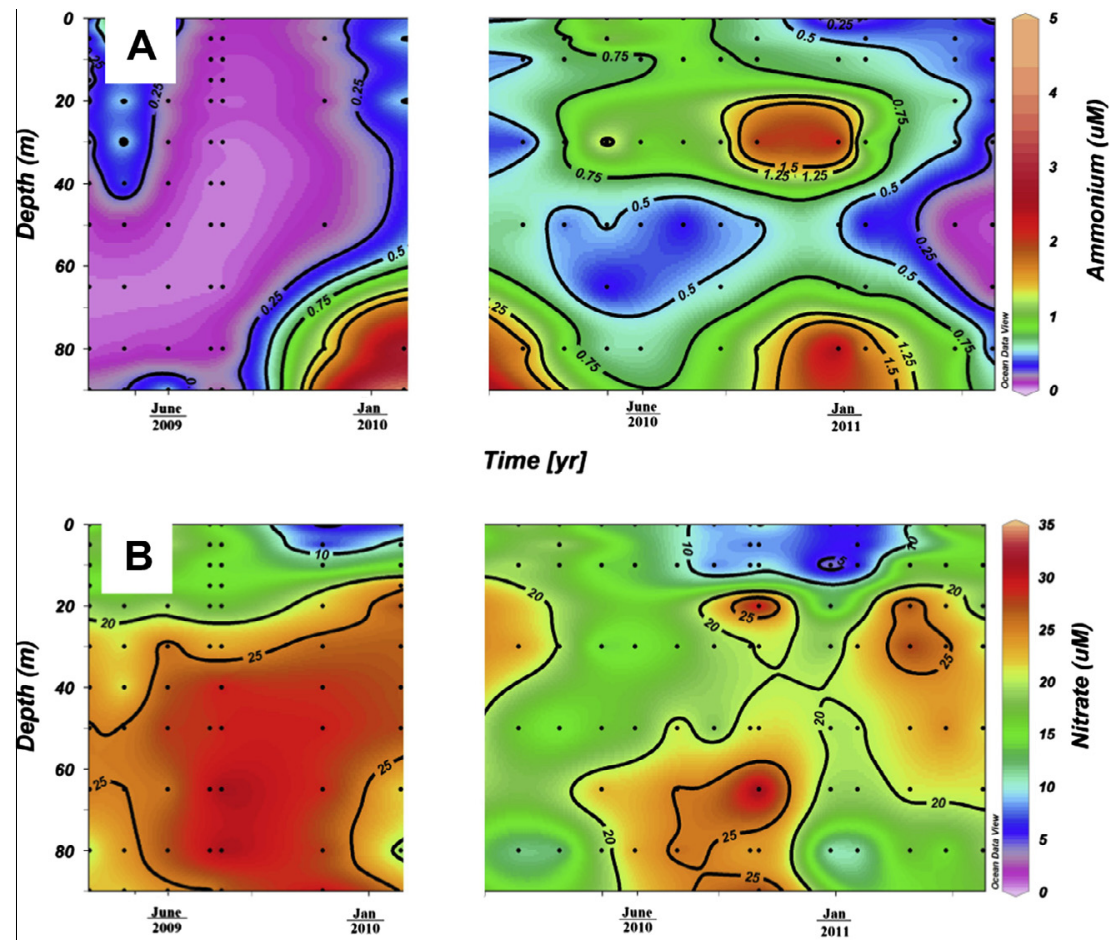

Time [yr]
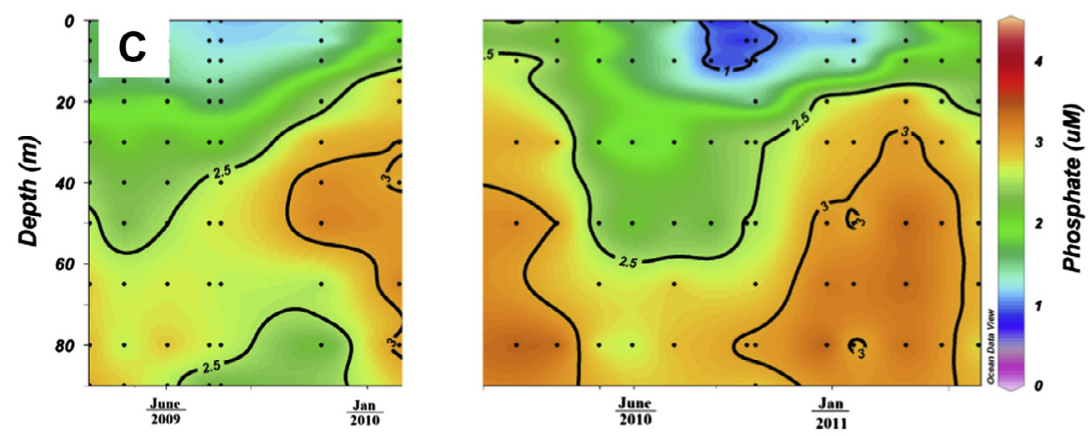

Time $[y r]$
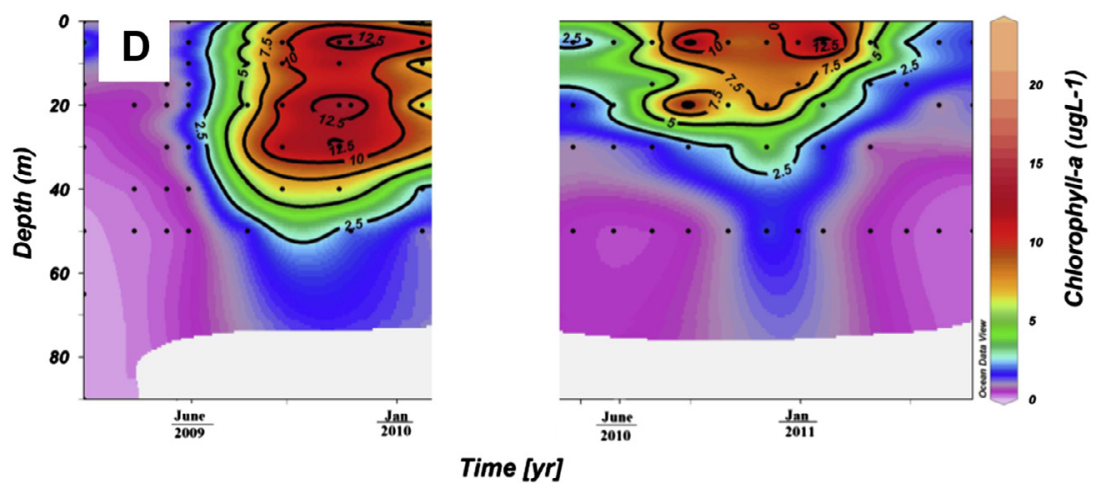

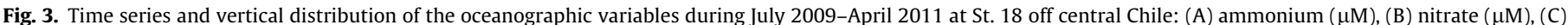
phosphate $(\mu \mathrm{M})$, and (D) July 2009-December 2010, Chl-a concentration $\left(\mu \mathrm{g} \mathrm{L}^{-1}\right)$.

market dissolved $\mathrm{O}_{2}$ decreases towards the bottom waters, with dissolved $\mathrm{O}_{2}$ concentration reaching values as low as $5 \mu \mathrm{mol} \mathrm{L} \mathrm{L}^{-1}$. This vertical pattern suggests that the anoxic sediments and even the bottom waters are the main $\mathrm{CH}_{4}$ source for the whole water column, which is subjected to an upward advection by upwelling. Table 3 shows $\mathrm{CH}_{4}$ inventories in the mixed and subsurface layer, the latter spanning from the base of the thermocline (or the base of the mixed layer) down to the sediment interface. Estimated $\mathrm{CH}_{4}$ inventories revealed that the subsurface $\mathrm{CH}_{4}$ pool size is 4to 6 -fold greater than the $\mathrm{CH}_{4}$ accumulated within the mixed layer, and that the $\mathrm{CH}_{4}$ increased levels between early spring to late summer responded to successive organic matter cumulative events during the 2010-2011 upwelling season (see Table 3). The biogeochemical $\mathrm{O}_{2}$ demand associated with organic matter decay, along 
A

Chl-a (ug/L)
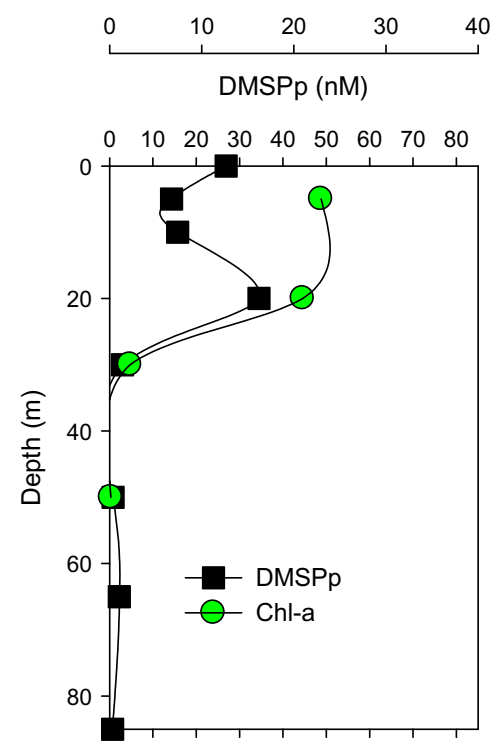

C
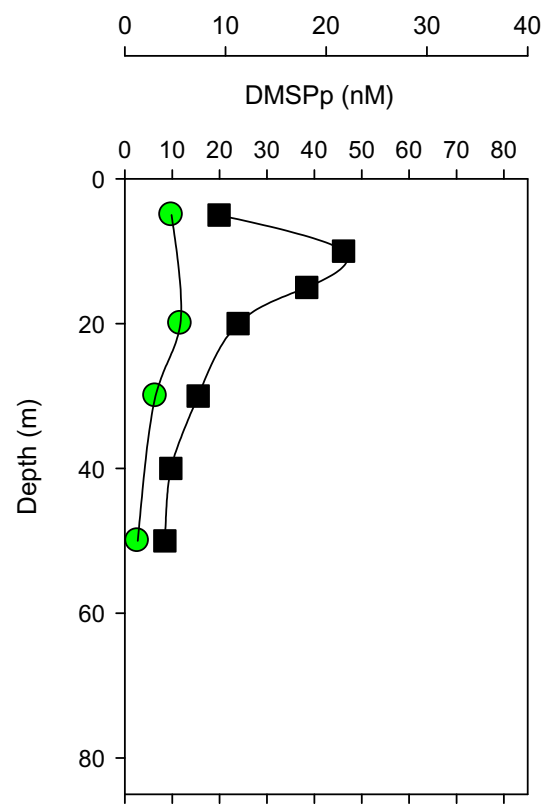

B Chl-a (ug/L)

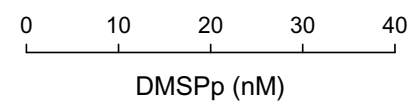

$\begin{array}{lllllllll}0 & 10 & 20 & 30 & 40 & 50 & 60 & 70 & 80\end{array}$

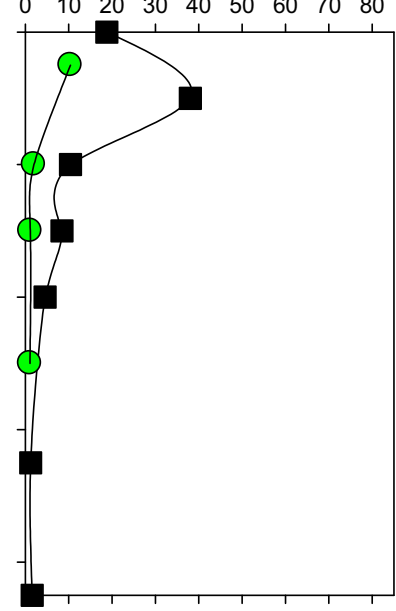

D Chl-a (ug/L)

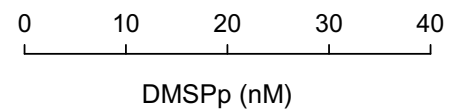

$\begin{array}{lllllllll}0 & 10 & 20 & 30 & 40 & 50 & 60 & 70 & 80\end{array}$

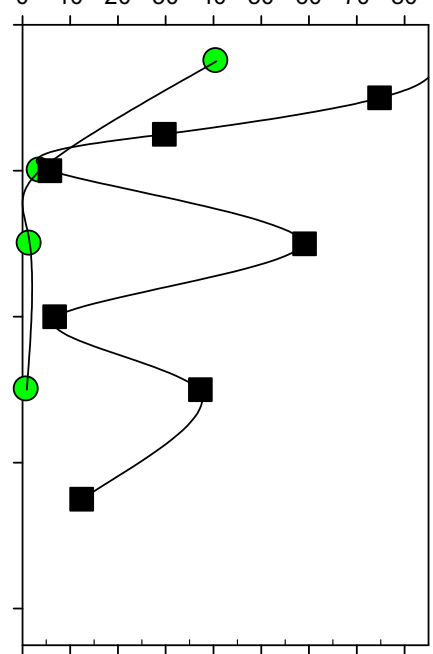

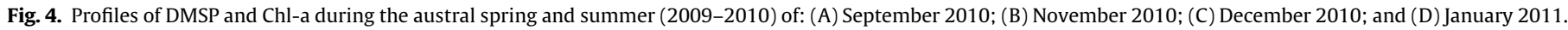

Table 2

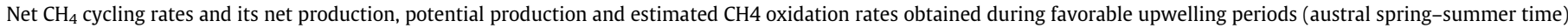
in two consecutive years (2009-2011).

\begin{tabular}{|c|c|c|c|c|c|c|c|c|}
\hline \multirow[t]{2}{*}{ Rates $\left(\mathrm{nM} \mathrm{d}^{-1}\right)$} & \multirow{2}{*}{$\begin{array}{l}\text { Period } \\
\text { Treatments }\end{array}$} & \multicolumn{2}{|l|}{2009} & \multicolumn{3}{|l|}{2010} & \multicolumn{2}{|l|}{2011} \\
\hline & & August & September & September & October & December & January & March \\
\hline Net $\mathrm{CH}_{4}$ cycling & Control & $-2.64 \pm 1.44$ & $1.44 \pm 0.24$ & ND & $1.2 \pm 0.72$ & $-0.64 \pm 1.68$ & $-0.29 \pm 0.20$ & $-0.41 \pm 0.12$ \\
\hline $\mathrm{CH}_{4}$ production ${ }^{\mathrm{a}}$ & Acetylene & ND & $\begin{array}{l}0.96 \pm 0.24 \\
(P<0.001)\end{array}$ & $\begin{array}{l}5.53 \pm 0.24 \\
\text { ND }\end{array}$ & $\begin{array}{l}7.08 \pm 0.96 \\
(P=0.00)\end{array}$ & $\begin{array}{l}4.0 \pm 1.66 \\
(P<0.05)\end{array}$ & $\begin{array}{l}2.61 \pm 0.48 \\
(P<0.001)\end{array}$ & ND \\
\hline Potential $\mathrm{CH}_{4}$ production & DMS Spike & $\begin{array}{l}-1.20 \pm 1.20 \\
(P=0.15)\end{array}$ & $\begin{array}{l}1.68 \pm 0.07 \\
(P<0.001)\end{array}$ & $\begin{array}{l}-0.96 \pm 0.48 \\
(P<0.05)\end{array}$ & $\begin{array}{l}2.64 \pm 1.92 \\
(P=0.002)\end{array}$ & $\begin{array}{l}4.56 \pm 0.48 \\
(P<0.005)\end{array}$ & $\begin{array}{l}-0.98 \pm 0.30 \\
(P<0.001)\end{array}$ & $\begin{array}{l}1.03 \pm 0.64 \\
P=\text { ND }\end{array}$ \\
\hline $\mathrm{CH}_{4}$ consumption $^{\mathrm{b}}$ & Estimation & $\mathrm{NE}$ & $-0.48 \pm 0.33$ & NE & $5.82 \pm 1.21$ & $4.64 \pm 2.36$ & $2.90 \pm 0.52$ & $\mathrm{NE}$ \\
\hline
\end{tabular}

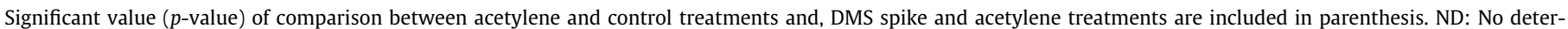
mined; NE: no estimated.

a Microbial assemblage sensitive to $\mathrm{C}_{2} \mathrm{H}_{2}$.

b Difference between acetylene minus control treatments. 
(A) Experiment September 2009

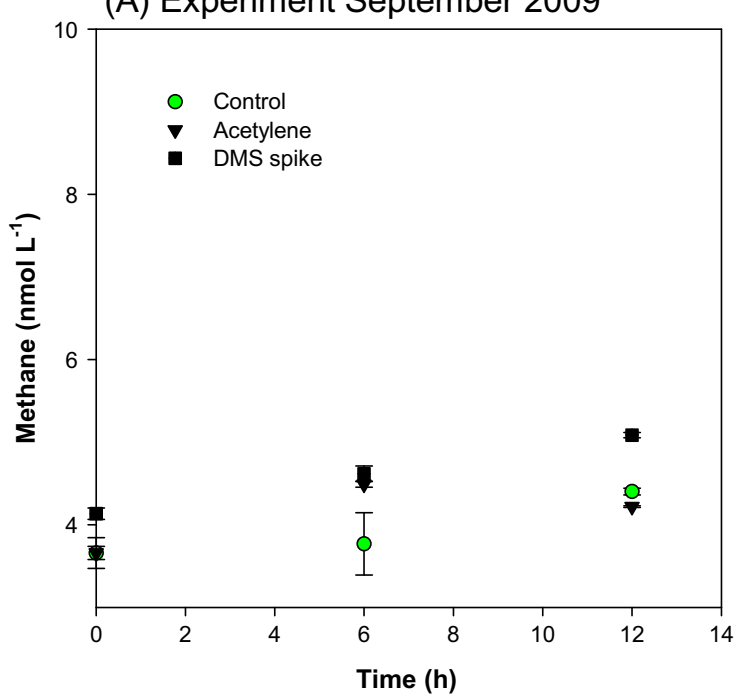

(B) Experiment October 2010

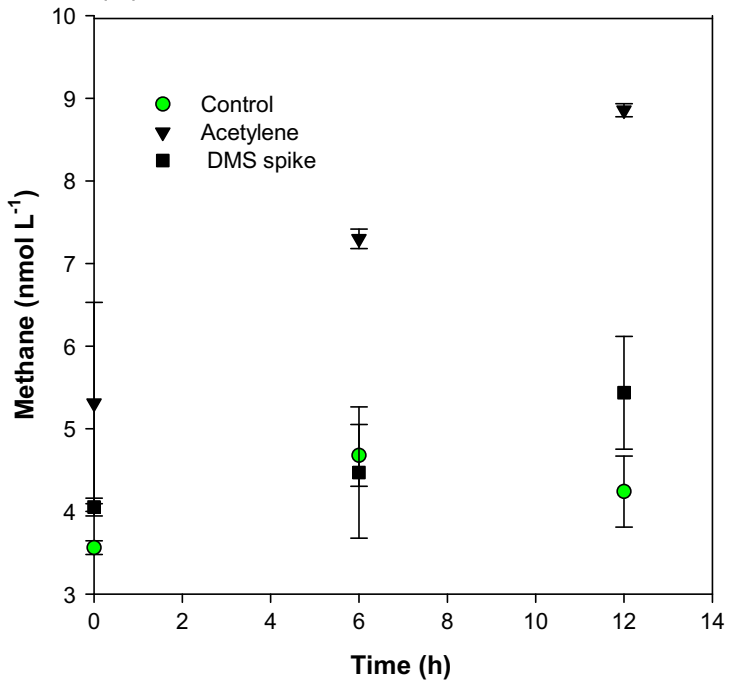

Fig. 5. Typical example of time course experiments of $\mathrm{CH}_{4}$ cycling under different treatments (A) control (without any addition) represent net $\mathrm{CH}_{4}$ cycling; (B) with $\mathrm{C}_{2} \mathrm{H}_{2}$ preventing potential consumption by methane oxidation; and (C) with a spike of DMS (final concentration of $6 \mathrm{nmol} \mathrm{L}^{-1}$ ).

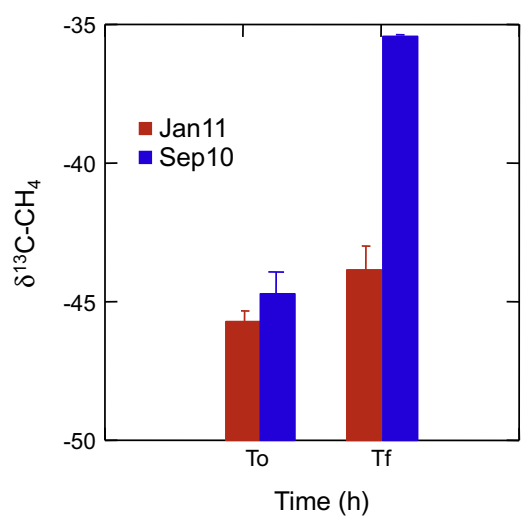

Fig. 6. Stable carbon isotopic composition of methane (expressed as delta) during sampling incubations, before and after the addition of ${ }^{13} \mathrm{C}$-DMS at Station 18 on the continental shelf off central Chile. Experiments were carried out in small bottles $(20 \mathrm{~mL})$ during September 2010 (A), January 2011 (B). with pre-existing low $\mathrm{O}_{2}$ concentrations following the distribution of ESSW (Paulmier et al., 2006), triggered the high production and accumulation of $\mathrm{CH}_{4}$ in the sediments and even within the water column.

In fact, an intense vertical advection by coastal upwelling accelerated the vertical transport of $\mathrm{CH}_{4}$ towards the surface during the spring-summer season, also leading to the rise of thermocline (Fig. 2A), oxycline, (Fig. 2C) and nutricline (Fig. 3B and C). This process causes surface fertilization (reflected by Chl-a; Fig. 3D) and degasification (reflected by $\mathrm{CH}_{4}$; Fig. 2D). Upon observing the $\mathrm{CH}_{4}$ time series in surface waters, $\mathrm{CH}_{4}$ concentrations were always oversaturated (123-550\%), forming sometime structures with high $\mathrm{CH}_{4}$ accumulation in the mixed layer, a pattern that may indicate of a local production.

Methane flux across the air-sea interface, estimated from the gas transference velocity $\left(k \mathrm{~cm} \mathrm{~h}^{-1}\right), \mathrm{CH}_{4}$ concentration measured in the mixed layer and those $\mathrm{CH}_{4}$ concentrations in relative equilibrium with the current atmospheric concentration, were calculated according Broecker and Peng equation modified by Wanninkhof (1992). These estimates indicated that gas exchanges were always positive (efflux) and ranged from 11 to as high as $115 \mu \mathrm{mol} \mathrm{m} \mathrm{m}^{-2}$ $\mathrm{d}^{-1}$, with high variability mainly controlled by favorable upwelling wind velocities and to a lesser degree by the $\mathrm{CH}_{4}$ content in the mixed layer.

These effluxes were relatively high with respect to other coastal areas (see Bange, 1994) and comparable with $\mathrm{CH}_{4}$ emissions from other coastal upwelling areas (Monteiro et al., 2006; Kock et al., 2008). $\mathrm{CH}_{4}$ emission has been indirectly linked to high primary productivity, which favors $\mathrm{CH}_{4}$ formation in sinking organic particles or in sediments (Owens et al., 1991; Sansone et al., 2001; Monteiro et al., 2006; Reeburgh, 2007). But as shown in Table 2, the experimental work in this study indicated that part of the $\mathrm{CH}_{4}$ contents seems to come from the surface waters and that such produced gas could be emitted to the atmosphere. In fact, in situ $\mathrm{CH}_{4}$ production at surface waters and vertical transport through the pycnocline should occur at higher rates in order to compensate $\mathrm{CH}_{4}$ loss by effluxes and consumption (i.e., aerobic $\mathrm{CH}_{4}$ oxidation). Thus, $\mathrm{CH}_{4}$ effluxes represent $8-169 \%$ of depth integrated $\mathrm{CH}_{4}$ production rates, which replace respective surface pools, between 0.8 and 5.2 days (see Table 3 ).

\subsection{Rates of methane produced in surface waters}

Methane formation is relatively certain in surface waters located outside anoxic areas. For instance, distinctive superficial peaks, some of which are located at the base of the photic layer, have frequently been described in marine environments (Lamontagne et al., 1973; Holmes et al., 2000), leading to the discussion on $\mathrm{CH}_{4}$ sources in such layers. New insights reveal that $\mathrm{CH}_{4}$ could be a by-product during the cycling of MPn or DMSP, but both mechanisms seem to be dependent on strong limitations or co-limitation of nutrients that trigger utilization of the compound (Karl et al., 2008; Damm et al., 2010). However, in the coastal upwelling off central Chile, high nutrient levels were observed throughout $\mathrm{NO}_{3}^{-}$and $\mathrm{PO}_{4}^{3-}$ during the study period (Fig. 3), and never a nutrient depletion was found even during winter (Morales and Anabalón, 2012).

Our results indicate that net $\mathrm{CH}_{4}$ production rates were positive (net accumulation) in most of the experiments done in surface waters during two consecutive upwelling periods, with rates fluctuating between 0.96 and $5.5 \mathrm{nmol} \mathrm{d}^{-1}$. Moreover, DMS-spiked experiments produced higher $\mathrm{CH}_{4}$ cycling rates, from $20 \%$ to 8 -fold, compared with control experiments (see Table 2), suggesting that an increase of $\mathrm{CH}_{4}$ production follows the addition of DMS.

Besides an increment of net production rates, the isotopic composition of $\mathrm{CH}_{4}$ after the addition of DMS (99\% enriched in ${ }^{13} \mathrm{C}$ ) 
Table 3

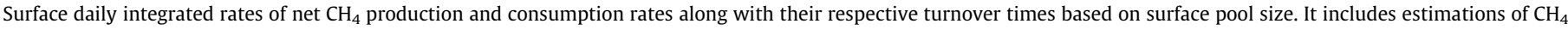
air-sea exchange during coastal upwelling period (2010-2011).

\begin{tabular}{|c|c|c|c|c|c|}
\hline \multirow[t]{2}{*}{ Parameters } & \multicolumn{3}{|l|}{2010} & \multicolumn{2}{|l|}{2011} \\
\hline & October & November & December & January & March \\
\hline Integrated net production rate $\left(\mu \mathrm{mol} \mathrm{m}{ }^{-2} \mathrm{~d}^{-1}\right)$ & $141 \pm 19$ & ND & $80 \pm 33$ & $52 \pm 9.6$ & $45 \pm 4.0$ \\
\hline Integrated net consumption rate $\left(\mu \mathrm{mol} \mathrm{m} \mathrm{m}^{-2} \mathrm{~d}^{-1}\right)$ & $116 \pm 24$ & ND & $93 \pm 47$ & $58 \pm 16$ & $53 \pm 4.6$ \\
\hline Surface inventory $\left(\mu \mathrm{mol} \mathrm{m}{ }^{-2}\right)$ & 108 & 236 & 324 & 141 & 236 \\
\hline Subsurface inventory $\left(\mu \mathrm{mol} \mathrm{m}{ }^{-2}\right.$ ) & 975 & 1716 & 1487 & 2470 & 2371 \\
\hline Air-sea $\mathrm{CH}_{4}$ flux ${ }^{\mathrm{a}}\left(\mu \mathrm{mol} \mathrm{m}{ }^{-2} \mathrm{~d}^{-1}\right)$ & 11.4 & 124 & 41.1 & 20.8 & 76.3 \\
\hline Surface turnover ${ }^{\mathrm{b}}$ (days) & $0.76(0.92)$ & $\mathrm{NE}$ & $4.0(3.5)$ & $2.7(2.4)$ & $5.2(4.4)$ \\
\hline
\end{tabular}

a Air-sea fluxes based on mean $\mathrm{CH}_{4}$ concentration in the mixed layer and piston velocities (wind velocities fluctuating 3.5 and $15.6 \mathrm{~m} \mathrm{~s}{ }^{-1}$ ) according Wanninkhof (1992).

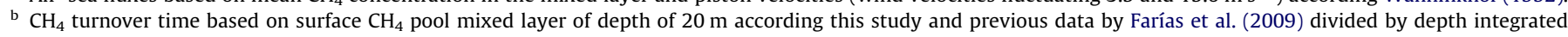
production and consumption rates (parenthesis values). ND: no determined: NE: no estimated.

revealed a significant enrichment in its heavier Carbon isotope after $12 \mathrm{~h}$ of incubation (i.e. $-35.43 \%$ to $-43.85 \%$ PDB) in relation to the natural $\mathrm{CH}_{4}$ isotopic signals and those obtained from experiments poisoned with $\mathrm{HgCl}_{2}$ (a poison for most microbes) (Fig. 6). It is important to note that natural $\delta^{13} \mathrm{C}^{-} \mathrm{CH}_{4}$ values (i.e. $-44.71 \%$ o to $-45.72 \%$ PDB) are comparable to those values found in natural systems subject to considerable $\mathrm{CH}_{4}$ oxidation (Sansone et al., 2001), as $\mathrm{CH}_{4}$ oxidation leaves the residual $\mathrm{CH}_{4}$ pool slightly enriched in ${ }^{13} \mathrm{C}$ in comparison to the atmospheric background of $-47 \%$ PDB) because of the favored microbial use of ${ }^{12} \mathrm{C}$ relative to ${ }^{13} \mathrm{C}$ in $\mathrm{CH}_{4}$ (Coleman et al., 1981; Sasakawa et al., 2008). This finding directly shows that part of the $\mathrm{CH}_{4}$ came from DMS added to the experiment while the extent of the enrichments in relation to natural measured values suggests that $\mathrm{CH}_{4}$ production varied according to the period of time.

As the exceeding rates of $\mathrm{CH}_{4}$ production follows the addition of DMS (Table 2), we postulate that $\mathrm{CH}_{4}$ formation came from during the demethylation of DMS due to an increase in the dissolved methyl group $\left(\mathrm{R}-\mathrm{CH}_{3}\right)$, and its subsequent reduction (electron gain) during the oxidation of the methylated compound. This process may be mediated via methylotrophic microorganism activity.

Although coastal upwelling systems are not areas with high levels of DMS, in contrast to the Southern and Arctic Oceans (Gabric et al., 2005; Rellinger et al., 2009), they could have high DMSP and DMS transient accumulations and, therefore, their respective DMSP/DMS turnovers associated with microbiological communities (Vila-Costa et al., 2008) could be higher as well. In addition, the DMSPp:Chl-a ratio, used to estimate the proportion of algal DMSP-producers in natural phytoplankton assemblages, displayed great variation throughout this study (see Table 1 ), with ratios as


at the beginning of the upwelling season. This may correspond to a shift in phytoplanktonic communities from large pennate diatoms (during spring or early upwelling) to smaller dinoflagellates and picophytoeukariote assemblages during the maturation of upwelling (González et al., 2007; Morales et al., 2007; Collado-Fabbri et al., 2011).

These results raise questions regarding which microbes are benefited by the additions of S- and C-rich organic substrates, such as DMS, and how (functional pathways) they may be responsible for such $\mathrm{CH}_{4}$ production. There are two possibilities: methanogens are present and active in the surface waters or other heterotrophic bacteria like methylotrophs are mediating $\mathrm{CH}_{4}$ production. Most substrates for methanogens and methylotrophs, such as methylamine and methyl groups from glycine betaine (GBT), trimethylamine (TMA), trimethylamine N-oxide (TMAO), and DMSP/DMS (Cicerone and Oremland, 1988; Finster et al., 1992; Van der Maarel, 1997) are shared by both groups (except acetate used only by methanogens). It is important to remark that DMSP/DMS are among the most abundant compounds in the surface waters, being synthesized by phototrophs (Vila-Costa et al., 2008). DMS-degradation is ascribed to methanogenic archaea (Kiene et al., 1986; Kiene and Visscher, 1987) and methylotrophic bacteria (Vissher et al., 1994) that derive energy from the conversion of methyl into other products, and also use $S$ as a source for the biosynthesis of methionine (Kiene et al., 1999).

Current studies based on natural and cultivated SAR11 Alphaproteobacteria (strain Ca. P. ubique HTCC1062; Sun et al., 2011) indicate that these microorganisms, some of the most abundant heterotrophic bacteria in surface waters, have genes that encode for oxidation pathways of a variety of one-carbon compounds, and they possess the capacity for demethylation and $\mathrm{C} 1$ oxidation, but do not incorporate $\mathrm{C} 1$ as biomass. These findings suggest the important role of this assemblage in obtaining energy from these compounds, and in mediating dissolved organic carbon cycling into $\mathrm{CO}_{2}$ in the upper ocean (Sun et al., 2011). Neufeld et al. (2008) demonstrated that active marine methylotrophs belonging to the Alphaproteobacteria and Gammaproteobacteria are associated with phytoplankton blooms in coastal environments, which in turn, and depending on the phytoplankton species, provide substrates for methylotrophs and mediate $\mathrm{CH}_{4}$ production. Additionally, in a microcosm experiment where $\mathrm{CH}_{4}$ is formed in DMSP spiked seawater, the CARD-FISH analysis shows that Archaea remained negligible in the DMSP supplemented approaches while Bacteria became nearly $100 \%$ of the community and alpha and gamma-proteobacteria together accounted for more than $75 \%$ of the DAPI-stained cells (Damm et al., 2010). Recent observations indicated that Alphaproteobacteria (including SAR11) and Rodobacteria are dominant in upwelling system off central Chile (Pommier et al., 2007; Aldunate, personal communication). The cosmopolitan distribution of Alphaproteobacteria supports the hypothesis that these bacteria are able to produce $\mathrm{CH}_{4}$ in surface waters. However, ongoing research is required to prove the proposed pathways.

\subsection{Potential AMO contribution to methane consumption rates}

Interestingly, although $\mathrm{CH}_{4}$ microbial oxidation occurs throughout the water column and is recognized to be an important process that reduces $\mathrm{CH}_{4}$ emissions (Reeburgh et al., 1993; Rehder et al., 1999), the microbial community mediating aerobic $\mathrm{CH}_{4}$ oxidation has scarcely been investigated. If net cycling rates (production minus consumption) are corrected with the apparent $\mathrm{CH}_{4}$ production $\left(\mathrm{C}_{2} \mathrm{H}_{2}\right.$ experiments), an apparent aerobic $\mathrm{CH}_{4}$ consumption rate could be obtained. Given that $\mathrm{C}_{2} \mathrm{H}_{2}$ is considered as an effective inhibitor of the MMO enzyme (Hanson and Hanson, 1996) and assuming that most methanotrophs are sensitive to $\mathrm{C}_{2} \mathrm{H}_{2}$, our cycling rates should represent methanotrophic activity.

Considering that our rates are representative of surface waters (Table 2), their integrated rates in surface or mixing layers can reduce $\mathrm{CH}_{4}$ pool size between 0.9 and 4.2 days (Table 3 ), highlighting 
the relevance of methanotrophic activity in partially reducing the emission of this gas towards the atmosphere. Although there are few measurements of aerobic $\mathrm{CH}_{4}$ oxidation in marine environments, our estimated rates are considerably higher than $\mathrm{CH}_{4}$ oxidation rates found in open systems under oligotrophic regimes (Tilbrook and Karl, 1995; Holmes et al., 2000), but are similar to those measured in the oxic waters of the Black Sea (Reeburgh et al., 1991; Gal'chenko et al., 2004). However, in these systems there is a marked increase in the magnitude of $\mathrm{CH}_{4}$ oxidation rates towards the oxic/anoxic interface, suggesting that oxidation is stimulated in areas where strong redox gradients are present.

An early study reported mean aerobic $\mathrm{CH}_{4}$ oxidation rates of $10 \mathrm{nmol} \mathrm{d}^{-1}$ when DIN levels were less than $5 \mu \mathrm{mol} \mathrm{L}^{-1}$, however with DIN as high as $16 \mu \mathrm{mol} \mathrm{L}^{-1}, \mathrm{CH}_{4}$ oxidation rates were as high as $210 \mathrm{nmol} \mathrm{d}^{-1}$ (Sansone and Martens, 1978). These findings, along with physiological similarities between methanotrophic and ammonia oxidizing bacteria, suggest the possibility that ammonia oxidizing microorganisms could be utilizing $\mathrm{CH}_{4}$ during their metabolic activities. Finally, our studied system, as seen in other systems with similar characteristics, is recognized as a hotspot of chemosynthetic activity, where high rates of dark carbon assimilation are measured, even in surface waters, given the high availability of electron donors other than organic matter in both surface and subsurface waters, such as $\mathrm{NH}_{4}^{+}$for ammonia oxidizing microorganisms (Farías et al., 2009) Here, large amounts of $\mathrm{NH}_{4}^{+}$, $\mathrm{CH}_{4}$ and even $\mathrm{HS}^{-}$are able to channel large amounts of chemical energy for the generation of organic matter (dark carbon assimilation). This is also the case of the Cariaco Basin (Taylor et al., 2001), the Black Sea (Wakeham et al., 2004), the Arabian Sea (Owens et al., 1991).

\section{Conclusion}

The results found here are relevant to climate studies given that the amount of "unknown" $\mathrm{CH}_{4}$ in surface layers may be substantial in areas where DMS has high turnovers. Thus, a positive climatic feedback mechanism could be produced, destroying DMS (with cooling effects) and producing $\mathrm{CH}_{4}$ (with a greenhouse effect), thereby affecting the radiative balance of the atmosphere.

\section{Acknowledgements}

We are grateful to Ronald Kiene for DMSP analyses. The authors thank Meike Vogt, Alison Relinger for their advice and assistance with DMSP, and Juan Faúndez and Gerardo Garcia for field assistance and expertise during cruise and laboratory work. Funds were provided by the Gordon and Betty Moore Foundation and FONDECYT \# 1120719 (Fondo Nacional de Investigaciones Cientificas y Tecnologicas Chile). It is a contribution to FONDAP \#1511009.

\section{References}

Anabalón, V., Morales, C.E., Escribano, R., Varas, M.A., 2007. The contribution of nano- and micro-planktonic assemblages in the surface layer $(0-30 \mathrm{~m})$ under different hydrographic conditions in the upwelling area off Concepción, central Chile. Progress in Oceanography 75, 396-414.

Andreae, M.O., 1985. The emission of sulfur to the remote atmosphere, p s-25. In: Galloway, J. et al. (Eds.), The Biogeochemical Cycling of Sulfur and Nitrogen in the Remote Atmosphere. Reidel, Dordrecht, pp. 331-362.

Andreae, M.O., 1990. Ocean-atmosphere interaction in the global biogeochemica sulfur cycle. Marine. Chemistry 30, 1-29.

Bange, H.W., Bartell, U.H., Rapsomanikis, S., Andreae, M.O., 1994. Methane in the Baltic and North Seas and a reassessment of the marine emissions of methane. Global Biogeochemical. Cycles 8, 465-480.

Bange, H.W., 2006. Nitrous oxide and methane in European coastal waters. Estuarine, Coastal and Shelf Science 70, 361-374.

Bates, T.S., Kelly, K.C., Johnson, J.E., Gammon, R.H., 1996. A reevaluation of the open ocean source of methane to the atmosphere. Journal of Geophysical Research 101, 6953-6961.
Brooks, J.M., Reid, D.F., Bernard, B., 1981. Methane in the upper water column of the northwestern Gulf of Mexico. Journal Geophysical Research 86, 11029-11040.

Cicerone, R.J., Oremland, R.S., 1988. Biogeochemical aspects of atmospheric methane. Global Biogeochemical Cycles 2, 299-327.

Collado-Fabbri, S., Vaulot, D., Ulloa, O., http://dx.doi.org/10.4319/lo.2011.56.6.2334, 2011. Structure and seasonal dynamics of the eukaryotic picophytoplankton community in a wind-driven coastal upwelling ecosystem. Limnology and Oceanography 56(6), 2334-2346.

Coleman, D.D., Risatti, J.B., Schoell, M., 1981. Fractionation of carbon and hydrogen isotopes by methane oxidizing bacteria. Geochimica et Cosmochimica Acta 45, 1033-1037.

Cornejo, M., Farías, L., Gallegos, M., 2007. Seasonal variability in $\mathrm{N}_{2} \mathrm{O}$ levels and airsea $\mathrm{N}_{2} \mathrm{O}$ fluxes over the continental shelf waters off central Chile $\left(\sim 36^{\circ} \mathrm{S}\right)$. Progress in Oceanography 75, 383-395.

Cornejo, M., Farias, L., 2012. Meridional variability of incidental solar radiation and modeling factors in a coastal upwelling area $\left(36^{\circ}\right)$. Progress in Oceanography 92-95, 33-42.

Craig, H., 1957. Isotopic standards for carbon and oxygen and correction factors for mass-spectrometric analysis of carbon dioxide. Geochimica et Cosmochimica Acta 12, 133-149.

Neufeld, J.D., Boden, R., Moussard, H., Schäfer, H., Murrell, J.C., 2008. Substratespecific clades of active marine methylotrophs associated with a phytoplankton bloom in a temperate coastal environment. Applied and Environmental Microbiology 74, 7321-7328.

Damm, E., Helmke, E., Thoms, S., Schauer, U., Nöthing, E., Bakker, K., Kiene, R.P., 2010. Methane production in aerobic oligotrophic surface water in the central Artic Ocean. Biogeosciences 7, 1099-1108.

Farías, L., Fernández, C., Faúndez, J., Cornejo, M., Alcamán, M.E., 2009. Chemolithoautotrophic production mediating the cycling of the greenhouses gases $\mathrm{N}_{2} \mathrm{O}$ and $\mathrm{CH}_{4}$ in an upwelling ecosystem. Biogeosciences 6, 6205-6247.

Ferdelman, T.G., Lee, C., Pantoja, S., Harder, J., Bebout, B.M., Fossing, H., 1997. Sulfate reduction and methanogenesis in a Thioploca-dominated sediment off the coast of Chile. Geochimica et Cosmochimica Acta 61, 3065-3079.

Fernandez, C., Farías, L., http://dx.doi.org/10.3354/meps09683, 2012. Assimilation and regeneration of inorganic nitrogen in a coastal upwelling system: ammonium and nitrate utilization. Marine Ecology Progress Series.

Finster, K., Tanimoto, Y., Bak, F., 1992. Fermentation of methanethiol and dimethylsulfide by a newly isolated methanogenic bacterium. Archives of Microbiology 157, 425-430.

Gabric, A.G., Qu, Bo., Matrai, P., Hirst, A.C., 2005. The simulated response of dimethylsulfide production in the Artic Ocean to global warming. Tellus 57B, 391-403.

Gal'chenko, V.F., Lein, A.Y., Ivanov, M.V., 2004. Rates of microbial production and oxidation of methane in the bottom sediments and water column of the Black Sea. Microbiology 73, 271-283.

González, H.E., Menschel, E., Aparicio, C., Barriga, C., 2007. Spatial and temporal variability of microplankton and detritus, and their export to shelf sediment in the upwelling area off Concepción, Chile $\left(\sim 36^{\circ} \mathrm{S}\right)$ during 2002-2005. Progress in Oceanography $75,435-451$.

Hanson, R.S., Hanson, T.E., 1996. Methanotrophic bacteria. Microbiology and Molecular Biology Reviews 60 (2), 439-471.

Hatton, A.D., Malin, G., Liss, P.S., 1999. Distribution of biogenic sulphur compounds during and just after the southwest monsoon in the Arabian Sea. Deep Sea Research II 46, 617-632.

Holmes, M.E., Sansone, F.J., Rust, T.M., Popp, B.N., 2000. Methane production, consumption, and air-sea exchange in the open ocean: an evaluation based on carbon isotopic ratios. Global Biogeochemical Cycles 14, 1-10.

Jessen, G.L., Pantoja, S., Gutierrez, M.A., Quiñones, R., Gonzalez, R.R., Sellanes, J., Kellermann, M.Y., Hinrichs, K.-U., 2011. Methane in shallow cold seeps at Mocha Island off central Chile. Continental Shelf Research 31 (6), 574-581.

Hyman, M.R., Arp, D.J., 1992. $14 \mathrm{C}_{2} \mathrm{H}_{2}$ and $14 \mathrm{CO}_{2}$ labeling studies of the de novo synthesis of polypeptides by Nitrosomonas europaea during recovery from acetylene and light inactivation of ammonia monooxygenase. Journal of Biological Chemistry 267 (3), 1534-1545.

Karl, D.M., Tilbrook, B.D., 1994. Production and transport of methane in oceanic particulate matter. Nature $368,732-734$

Karl, D., Beversdorf, L., Björkman, K.M., Church, M.J., Martinez, A., DeLong, E.F., 2008. Aerobic production of methane in the sea. Nature Geoscience 1, 473-478.

Kiene, R.P., Oremland, R.S., Catena, A., Miller, L.G., Capone, D.G., 1986. Metabolism of reduced methylated sulfur-compounds in anaerobic sediments and by a pure culture of an estuarine methanogen. Applied and Environmental Microbiology 52, 1037-1045.

Kiene, R.P., Visscher, P.T., 1987. Production and rate of methylated sulfur compounds from methionine and dimethylsulfoniopropionate in anoxic salt marsh sediments. Applied and Environmental Microbiology 53 (10), 24262434

Kiene, R.P., Linn, L.J., Gonzalez, J., Moran, M.A., Bruton, J.A., 1999. Dimethylsulfoniopropionate and methanethiol are important precursors of methionine and protein-sulfur in marine bacterioplankton. Applied and Environmental Microbiology 65 (10), 4549-4558.

Kiene, R.P., Linn, L.J., Bruton, J.A., 2000. New and important roles for DMSP in marine microbial communities. Journal of Sea Research 43, 209-224.

Kiene, R.P., Slezak, D., 2006. Low dissolved DMSP concentrations in seawater revealed by small-volume gravity filtration and dialysis sampling. Limnology and Oceanography 4, 80-95. 
Kock, A., Gebhardt, S., Bange, H.W., 2008. Methane emissions from the upwelling area off Mauritania (NW Africa). Biogeosciences 5, 1119-1125.

Lana, A., Bell, T.G., Simó, R., Vallina, S.M., Ballabrera-Poy, J., Kettle, A.J., Dachs, J., Bopp, L., Saltzman, E.S., Stefels, J., Johnson J.E., Liss, P.S., http://dx.doi.org/ 10.1029/2010GB003850, 2011. An updated climatology of surface dimethlysulfide concentrations and emission fluxes in the global ocean. Global Biogeochemical Cycles 25, GB1004.

Lamontagne, R.A., Swinnerton, J.W., Linnenbom, V.J., Smith, W.D., 1973. Methane concentrations in various marine environments. Journal of Geophysical Research 78, 5317-5324.

Monteiro, P.M.S., van der Plas, A., Mohrholz, V., Mabille, E., Pascall, A., Joubert, W., http://dx.doi.org/10.1029/2006GL026234, 2006. Variability of natural hypoxia and methane in a coastal upwelling system: Oceanic physics or shelf biology? Geophysical Research Letters 33, L16614.

Morales, C.E., González, H.E., Hormazabal, S.E., Yuras, G., Letelier, J., Castro, L.R. 2007. The distribution of chlorophyll-a and dominant planktonic components in the coastal transition zone off Concepcion, central Chile, during different oceanographic conditions. Progress in Oceanography 75, 452-469.

Morales, C.E., Anabalón, V., http://dx.doi.org/10.1016/j.pocean.2011.07.004, 2012. Phytoplankton biomass and microbial abundances during the spring upwelling season in the coastal area off Concepción, central-southern Chile: variability around a time series station. Progress in Oceanography 92 (1), 81-91.

Moran, M., Reisch, C.R., Kiene, R.P., Whitman, W.B., 2012. Genomic insights into bacterial DMSP transformations. Annual Review of Marine Science 4, 523-542.

Naqvi, S.W.A., Bange, H.W., Farías, L., Monteiro, P.M.S., Scranton, M.I., Zhang, J., 2010 Marine hypoxia/anoxia as a source of $\mathrm{CH}_{4}$ and $\mathrm{N}_{2} \mathrm{O}$. Biogeosciences 7, 21592190.

Oremlad, R.S., 1979. Methanogenic activity in plankton sample and fish instestines: a mechanism for in situ methanogenesis in ocean surface water. Limnology and Oceanography 24, 1136-1141.

Owens, N.J.P., Law, C.S., Mantoura, R.F.C., Burkill, P.H., Lewellyn, C.A., 1991. Methane flux to the atmosphere from the Arabian Sea. Nature 354, 293-296.

Parsons, T., Maita, Y., Lali, C.M., 1985. A Manual of Chemical and Biological Methods for Seawater Analysis. Pergamon Press, pp. 172.

Paulmier, A., Ruiz-Pino., D., Garcon, V., Farias, L., http://dx.doi.org/10.1029/ 2006GL026801, 2006. Maintaining of the Eastern South Pacific oxygen minimum zone (OMZ) off Chile. Geophysical Research Letters 33(20), L20601.

Pommier, T., Canback, B., Riemann, L., Bostrom, K.H., Simu, K., Lundberg, P., Tunlid, A., Hagström, A., 2007. Global patterns of diversity and community structure in marine bacterioplankton. Molecular Ecology 16, 867-880.

Prior, S.D., Dalton, H., http://dx. doi:10.1111/j.1574-6968.1985.tb00843.x, 1985. Acetylene as a suicide substrate and active site probe for methane monooxygenase from Methylococcus capsulatus (Bath). FEMS Microbiol Lett 29,105-109. .

Quay, P., Stutsman, J., Wilbur, D., Snover, A., Dlugokencky, E.J., Brown, T., 1999. The isotopic composition of atmospheric methane. Global Biogeochemical Cycles $13,445-461$.

Reeburgh, W.S., 2007. Oceanic methane biogeochemistry. Chemical Reviews 107, 486-513.

Reeburgh, W.S., Ward, B.B., Whalen, S.C., Sandbeck, K.A., Kilpatrick, K.A., Kerkhof, L.J., 1991. Black Sea methane geochemistry. Deep-Sea Research II (38), S1189S1210.

Reeburgh, W.S., Whalen, S.C., Alperin, M.J., 1993. The role of methylotrophy in the global methane budget. In: Murrell, J.C., Kelly, P.D. (Eds.), Microbial Growth on C1 Compounds. Intercept, Andover, pp. 1-14.

Rehder, G., Keir, R.S., Suess, E., Rhein, M., 1999. Methane in the northern Atlantic controlled by microbial oxidation and atmospheric history. Geophysical Research Letters 26, 587-590.

Rehder, G., Collier, R.W., Heeschen, K., Kosro, P.M., Barth, J., Suess, E., http:// dx.doi.org/10.1029/2000GB001391, 2002. Enhanced marine $\mathrm{CH}_{4}$ emissions to the atmosphere off Oregon caused by coastal upwelling. Global Biogeochemical Cycles 16, 1081
Rellinger, A.N., Kiene, R., del Valle, D., Kieber, D., Slezak, D., Harada, H., Bisgrove, J., Brinkleyc, J., 2009. Occurrence and turnover of DMSP and DMS in deep waters of the Ross Sea, Antarctica. Deep-Sea Research I 56, 686-702.

Rudd, J.W.M., Taylor, C.D., 1980. Methane cycling in aquatic environments. Advance Aquatic Microbiology 2, 77-150.

Sellanes, J., Zapata-Hernández, G., Pantoja, S., Jessen, G.L., 2011. Chemosynthetic trophic support for the benthic community at an intertidal cold seep site at Mocha Island off central Chile. Estuarine, Coastal and Shelf Science 95 (4), 431439.

Sobarzo, M., Bravo, L., Donoso, D., Garcés-Vargas, J., Schneider, W., 2007. Coastal upwelling and seasonal cycles that influence the water column over the continental shelf off central Chile. Progress in Oceanography 75, 363-382.

Sansone, F.J., Martens, C.S., 1978. Methane oxidation in Cape Lookout Bight, North Carolina. Limnology and Oceanography 23, 349-355.

Sansone, F.J., Popp, B.N., Gasc, A., Graham, A.W., Rust, T.M., 2001. Highly elevated methane in the eastern tropical North Pacific and associated isotopically enriched fluxes to the atmosphere. Geophysical Research Letters 28, 45674570 .

Sasakawa, M., Tsunogai, U., Kameyama, S., Nakagawa, F., Nojiri, Y., Tsuda, A., http:// dx.doi.org/10.1029/2007JCOO4217, 2008. Carbon isotopic characterization for the origin of excess methane in subsurface seawater. Journal Geophysical Research 113, C03012.

Scranton, M.I., Brewer, P., 1977. Occurrence of methane in the near-surface waters of the western subtropical North Atlantic. Deep-Sea Research 24, 127-138.

Sowers, K.R., Ferry, J.G., 1983. Isolation and characterization of a methylotrophic marine methanogen, Methanococcoides methylutens, gen. nov., sp. nov. Applied and Environmental Microbiology 45, 684-690.

Sprott, G.D., Jarrell, K.F., Shaw, K.M., Knowles, R., 1982. Acetylene as an inhibitor of methanogenic bacteria. Journal of General Microbiology 128, 2453-2462.

Sun, J., Steindler, L., Thrash, J.C., Halsey, K.H., Smith, D.P., Carter, A.E., Landry, Z.C., Giovannoni, SJ., http://dx.doi.org/10.1371/journal.pone.0023973, 2011. One Carbon Metabolism in SAR11 Pelagic Marine Bacteria. PLoS ONE 6(8), e23973.

Taylor, G.T., Iabichella, M., Tung-yuan, H., Scranton, M., Thunell, R., Muller-Karger, F., Varela, R., 2001. Chemoautotrophy in the redox transition zone of the Cariaco Basin: a significant midwater source of organic carbon production. Limnology and Oceanography 46, 148-163.

Tilbrook, B.D., Karl, D.M., 1995. Methane sources, distributions and sinks from California coastal waters to the oligotrophic North Pacific gyre. Marine Chemistry 49, 51-64.

Traganza, E.D., Swinnerton, J.W., Cheek, C.H., 1979. Methane supersaturation and ATP- zooplankton blooms in near-surface waters of the Western Mediterranean and the subtropical North Atlantic Ocean. Deep-Sea Research Part I 26, 1237 1245.

Van der Maarel, Hansen T., 1997. Dimethylsulfoniopropionate in anoxic intertidal sediments: a precursor of methanogenesis via dimethylsufide, methanethiol and methyolpropionate. Marine Geology 137, 5-12.

Vila-Costa, M., Kiene, R.P., Simó, R., 2008. Seasonal variability of the dynamics of dimethylated sulphur compounds in a coastal northwest Mediterranean site. Limnology and Oceanography 53, 198-211.

Vissher, P.T., Kiene, R.P., Taylor, B.F., 1994. Demethylation and cleavage of demethylsulfoniopropionate in marine intertidal sediments. FEMS Microbiology Ecology 14, 179-190.

Wakeham, S.G., Hopmans, E.C., Schouten, S., Damsté, J.S.S., 2004. Archaeal lipids and anaerobic oxidation of methane in euxinic water columns: a comparative study of the Black Sea and Cariaco Basin. Chemical Geology 205, 427-442.

Wanninkhof, R., 1992. Relationship between wind speed and gas exchange over the ocean. Journal Geophysical Research 97, 7373-7382.

Weisenburg, D.A., Guinasso, N.L., 1979. Equilibrium solubilities of methane, carbon monoxide and hydrogen in water and seawater. Journal of Chemical Engineering Data 24, 354-360.

Wolfe, R.S., 1971. Microbial formation of methane. Advance Microbial Physiology 6 , 107-146.

Wuebbles, D.J., Hayhoe, K., 2002. Atmospheric methane and global change. EarthScience Reviews 57, 177-210. 